Available online at www.sciencedirect.com

www.cya.unam.mx/index.php/cya

Contaduría y Administración 60 (S1) 9-30

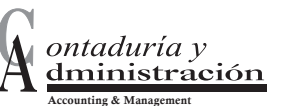

www.contaduriayadministracionunam.mx/

\title{
Research methods and methodology towards knowledge creation in accounting
}

\author{
Métodos de investigación y metodología hacia la creación \\ de conocimiento en contabilidad
}

\author{
Ilídio Tomás Lopes
}

University Institute Of Lisbon, ISCTE Business School, Portugal

Received 7 Abril 2014; acepted 2 octubre 2014

Available online 14 September 2015

\begin{abstract}
Academic and scientific research embodies the purist way to achieve new knowledge through diversified methods and methodologies. It aims to describe and interpret multiple phenomena and their impact on social and organizational developments. Based on 760 postgraduate completed academic researches, in the scientific fields of accounting, auditing, and management control, a set of variables was identified towards an integrated overview of methods and methodology that historically fit with those scientific fields. This paper aims to evidence whether those methods and methodology depend from the scientific field under research and identify their impact on theory construction and for organizations' development. Research in financial accounting tends to increase the positivist or mainstream approach while management accounting research is characterized by an integrated descriptive or interpretive approach. Furthermore, case studies are used as way of stregthening the linkage and cooperation between higher education institutions, in particular business schools, and external organizations.

E-mail address: ilidio.tomas.lopes@iscte.pt

Peer Review under the responsibility of Universidad Nacional Autónoma de México.

http://dx.doi.org/10.1016/j.cya.2015.08.006

0186-1042/All Rights Reserved ( 2015 Universidad Nacional Autónoma de México, Facultad de Contaduría y Administración. This is an open access item distributed under the Creative Commons CC License BY-NC-ND 4.0.
\end{abstract}


All Rights Reserved (C) 2015 Universidad Nacional Autónoma de México, Facultad de Contaduría y Administración.

This is an open access item distributed under the Creative Commons CC License BY-NCND 4.0.

Keywords: Research methods; Methodology in accounting; Financial accounting; Management accounting; Accounting education

\section{Resumen}

La investigación académica y científica encarna la manera purista para alcanzar nuevos conocimientos a través de métodos y metodologías diversificadas. Su objetivo es describir e interpretar múltiples fenómenos y su impacto en los acontecimientos sociales y organizativos. Sobre la base de 760 trabajos de investigaciones académicas, en los campos de la ciencia de la contabilidad, la auditoría y el control de gestión, se identificó un conjunto de variables hacia una visión integrada de los métodos y la metodología que se ajustan históricamente con los campos científicos. En este trabajo se pretende poner en evidencia si esos métodos y la metodología dependen del campo científico en la investigación e identificar su impacto en la construcción de teorías y para el desarrollo de las organizaciones. La investigación en contabilidad financiera tiende a aumentar el enfoque positivista o la corriente principal mientras que la investigación de contabilidad de gestión se caracteriza por un enfoque descriptivo o interpretativo integrado. Además, los estudios de casos se utilizan como forma de fortalecer la vinculación y cooperación entre las instituciones de educación superior, en las escuelas de negocios particulares y organizaciones externas.

Derechos Reservados@2015 Universidad Nacional Autónoma de México, Facultad de Contaduría y Administración.

Este es un artículo de acceso abierto distribuido bajo los términos de la Licencia Creative Commons CC BY-NC-ND 4.0.

Palabras clave: Métodos de investigación; Metodología de la contabilidad; Contabilidad financiera; Contabilidad de gestión; Enseñanza de la contabilidad

\section{Introduction}

The dynamic search of new knowledge covers a wide and integrated process of research in which individuals and groups act towards the dynamic identification and formulation of concepts, theories, principles, rules and procedures that are useful in the search of truth. Grouped by Aristotle in three distinct areas - Scientific, Technical, and Practice - men's survival lies on opinion (doxa) and technique (techne). In the world of ideas and concepts, men can attain true knowledge (épisthéme) through its curiosity and involvement as regards the discovery and development. Scientific progress, overtime, is based on the dynamic search for truth that instills in the natural and social world, order and rationality. These processes 
should anticipate and predict the world evolution on a fair and reliable basis. Thus, the contributions of researchers as Plato are really the continuous guide in that search towards those justified and paradigmatic true beliefs.

Over centuries, researchers always tried, indeed, to explain the essence of natural and social world. This systematic demand of truths has reshaped the traditional concepts of time and space, reinforcing in itself the scope and approaches of Plato's philosophy and postulates. His theory of ideas and forms ensures the intelligibility of each phenomenon as a perfect symbiosis between the intelligible and sensible reality. Using a more deductive or inductive methods, and probably away off the discussions around the most rationalistic or empirical outcomes, researchers as René Descartes, Kant, and Hegel, also seek for the identification of principles towards the best understanding of the natural and social phenomena. Becoming the core driver of each science, scientific and academic research efforts are the core activities, inside high education institutions and other research networks, to achieve a deep comprehension and knowledge sustainability. Far from the thoughts of Aristotle, Plato or even Descartes, the contributions of Immanuel Kant (appointed as the forefather of transcendental idealism) have exploited and structured new concepts and treatments, influencing the boundaries of the economic theories as a whole. In fact, Kantian's postulates, sought some convergence with the epistemological doctrines, in particular the empiricism, rationalism, realism, and idealism.

The dynamic search for knowledge is a paradigmatic abstraction in itself. Their multiple typologies — e.g. Tacit; Explicit; Cultural (Choo, 1996); Individual; Social (Von Krogh, 1998); Strategic; Tactical; Supportive (Sullivan, 2000); Codified; Tacit; Observable; Unobservable; Positive; Negative; Autonomous; Systematic (Teece, 1998) - have intersected the scope and objectives of each research, always seeking for a symbiotic adherence to particular phenomena. It will be certainly intelligible that in social sciences, classification of knowledge follows many of those types. Hence, the genesis of knowledge always lies in a set of assertions, formulated to instill the dynamic nature of those development and discoveries.

The efficiency of methodologies and methods in the process of knowledge capture and creation, depend on the circumstances in which it is originated, in which it is embodied and arose. Each knowledge level reflects the intensity of its aggregation and integration. In a pure ontological dimension, it is created by individuals, through their interaction inside groups and organizations, structured and exploited through dynamic and complex networks. The perception of its usefulness in the social world explanation could shape the methodologies and approaches as regards its capture, creation and dissemination. Researcher's intuition, judgment, experience, values, and rules, are the clue drivers in this systematic and sometimes lonely path. 
The concepts of knowledge creation, and research methods and methodology, were the key determinants for this research project ion scientific field of accounting and its related topics. It aims to identify the most structured approaches and methodologies that have driven, in the last decade, the academic research made in higher education institutions, especially across their concluded postgraduate projects. Structured around diversified methodologies, the development of those projects depends on its scientific domain, and on its intrinsic objectives. It becomes imperative to identify and categorize the main variables that fit, on a reliable basis, the methods and methodology used by students in their MSc and $\mathrm{PhD}$ programs. In order to clarify the trends in the accounting research, this paper aims to identify whether the research methods used in financial accounting and management accounting are convergent or divergent. Thus, the validated evidence emerged from this research can positively contribute with new insights for the theory development and to the linkage reinforcement between education and external organizations, such as private/public firms, private organizations, agencies and other educational and research networks.

\section{The dynamic search for new knowledge}

The semantic diversification around the concept of knowledge has been the result of multiple developments and changes in the paradigms about the natural and social world. Their multiple typologies are linked with each particular research objectives, and always seek for the maximization and adherence to the reality under analysis. Therefore, it will be scientifically understandable that, in social sciences (e.g. business; accounting; political science; etc.), the classification of knowledge takes many of those categories (e.g. Tacit; Explicit; Cultural; Individual; Social, etc.) that can possibly also emerge in the context of natural sciences.

Associated with the traditional classification between tacit and explicit knowledge, Choo (1996) refers to its existence, adding to this dichotomy a third type of knowledge - the Cultural Knowledge, embodied in individuals, groups, organizations, and societies. This type of knowledge translates a set of beliefs, even rules and procedures, that an organization or society holds based on experiences and observations. It is the reflection of how the organization performs, and on what it captures insights from the external environment. This cultural dimension, a fundamental pillar in the knowledge economy, affects the type and intensity in the use of organizational practices and performance.

Complimentarily, Teece (1998) also contributes with a wide variety of knowledge typologies. The dichotomy tacit/codified takes us into an abstract dimension in which 
individuals know more than what they can provide. This level of knowledge codification arises directly from the speed in which organizations promote and demand knowledge disclosure and use. The increase in the knowledge codification is usually in direct relation to its legal protection. The success or failure associated with technological innovation supports the Teece's classification in positive and negative knowledge. The possibility and need to modify the systems responsible for the creation and transfer supports the dichotomy between autonomous and systematic knowledge.

Knowledge levels reflect both the intensity of its aggregation and integration. In an ontological dimension, knowledge can be created at an individual level, inside groups, at an organizational level or within organizations. Thus, scientific and academic research links the higher education institutions and the external organizations as a whole, namely big companies, public institutes, and transnational normative boards. Through conceptual or applied approaches, those researches can contribute on a dynamic basis to the social value creation comprehensiveness. Academic projects constitute some of the immediate outcomes inside the academic communities, linking theoretical and applied knowledge, in a dynamic symbiosis of value creation. Complementarily, Tiwana (2000) argues the creation of new knowledge at an individual, departmental and networking level. This integration, bracketed with an increased perception of its degree of usefulness, reflects the essence of the dynamic process of capture and creation. Quinn et al. (1996) adds to this argumentation, four different levels of knowledge (cognitive, advanced competencies, systematic understanding, and creativity). While most of them are directly linked with organizational systems, repositories and operating technologies, creativity usually resides in the organizational culture and value added promotion. Furthermore, scientific and academic communities have a wide responsibility in that creativity and innovation promotion. Thus, to capture the state of the art about higher education scientific production, derived from their education policies, is the best way to evidence the effective linkage between academic institutions, scientific departments and external knowledge agents. Hence, knowledge creation inside higher education institutions and related organizations stems from the systematic combination of individuals as the main catalysts absorption of tacit knowledge. A specific set of R\&D activities promote and facilitate the academic innovation chain fitting the knowledge creation as a mission in itself. This interaction between problem solving, implementation, integration, experimentation and tacit/explicit knowledge capture, shape the innovation and prospective capacity of those scientific and academic communities. The intrinsic abilities of individuals, associated to the technological systems and organizational culture, contribute with their projects to the sustainable expertise achievements. 


\section{Research methods and methodology}

\section{Epistemological and ontological overview}

Scientific and academic research is traditionally structured around two different dimensions: the ontological dimension (associated to the objectivity/subjectivity level) and the epistemological dimension (as the way to acquire knowledge). The paradigms embedded in each research can derive on a sociological understanding of the natural and social world. According to Burrell and Morgan (1979), those understandings can be linked with two different perspectives which alignments derive in a more radical or functionalist view. The first structural spindle is based on the research level of subjectivity and the second is based on the society's structure, and related ways to interpret complex phenomena. Senik (2009) links this dimension to the status quo, social order, level of social integration and cohesion, solidarity driven orientation and satisfaction needs compliance.

From a single epistemological outlook, Sekaran and Bougie (2013) have defined an alternative classification for the most important perspectives of research in the business scientific fields, namely: Positivism; Constructionism; Critical realism; and Pragmatism. The positivist or mainstream approach evidences the way to achieve the truth, believing that it is always possible to predict that world. This is also a replicable research, based on its findings generalization. Through a deductive reasoning, cause and effect relations are tested within structured and multilateral frameworks. This hermetic point of view lies on the objective measures, on the direct observation and on the dismissal of research emotions and thoughts (Chua, 1986; Laughlin, 1995; Ryan et al., 2002; Sekaran and Bougie, 2013).

The second perspective of research assumes the assumption that the reality is mentally constructed (Sekaran and Bougie, 2013). Thus, this approach focus on the comprehensiveness of rules and procedures used to achieve connections in the real world. From this perspective, the capture and creation of knowledge is based on observations and interpretations of the social practices (Ryan et al., 2002). Its intrinsic qualitative nature drives researcher into an ontological dimension in which knowledge is created from the individual interaction within groups, organizations and networks (Von Krogh, 1998). As mentioned by Senik (2009), this perspective has social subjectivity and declared disagreement between positivist approaches.

Critical realism perspective is, in nature, an intermediary approach which lays its genesis on the assumption that an objective truth exists but cannot be objectively and reliably measured (Sekaran and Bougie, 2013). Individual, as an actor in each phenomenon interpretation, always biases its understanding, even whe- 
reas collecting emotions, feelings, attitudes or viewpoints. Behavioral theories can support those biases, especially phenomena that researcher cannot observe and measure directly as satisfaction, motivation, organizational or knowledge management culture and values. Finally, pragmatism emerges as a pluralist but practical perspective. Its transversal practical view aligns research methodologies as a mix of research aims and objectives, observable phenomena, and research questions. Since the world is dynamic, evidence always assumes a provisional nature.

\section{Towards accounting research}

Ontology dimension is associated to the human beliefs about the natural and social world while epistemology is linked to the search of new knowledge and the way how we go through. Although several approaches can be followed in this search (v.g. positivist or mainstream, interpretive; and critical), it "entails disagreement, criticism, chance and error" (Ryan et al., 2002, p. 1). Thus, a research method starts from a formulated theory, usually emerged from literature review, and derives in the form of a mathematical model or in an interpretive or critical systematization. Regardless of inference, it is intended that from this process may result new knowledge towards the confirmation or refutation of the theory that have been supporting each research.

The developments in the accounting research have been increased in the last decades. Based on multiple doctrinal thoughts, research in accounting seeks to understand social phenomena towards its harmonization and standardization. The developments in organizations have required from the academia additional insights towards economic value creation. Thus, education and academic research establish a mutual working relationship between academics and professionals in the industry, the required linkage to ensure the production of high quality accounting graduates that could become real assets in the social environment (Dandago and Shaari, 2013).

Structured around six basic topics (assumptions; prediction power and objectives; method used in data collection; nature of research; sampling; findings generalization power; and main business fields of research), the key characteristics and differences of each approach are summarized in the Table below. 
Table 1.

Research approaches and perspectives.

\begin{tabular}{|c|c|c|c|}
\hline & $\begin{array}{l}\text { Positive or } \\
\text { mainstream }\end{array}$ & Interpretive & Critical \\
\hline Assumptions & $\begin{array}{l}\text { Objectivity; } \\
\text { Realism; } \\
\text { Functionalism; } \\
\text { Social change }\end{array}$ & $\begin{array}{l}\text { Subjectivity; } \\
\text { Social regulation; } \\
\text { Mental constructivism }\end{array}$ & $\begin{array}{l}\text { Objectivity/Subjectivity; } \\
\text { Radical change }\end{array}$ \\
\hline $\begin{array}{l}\text { PREDICTION POWER AND } \\
\text { OBJECTIVES }\end{array}$ & Predictive & Usually non predictive & Non predictive \\
\hline $\begin{array}{l}\text { METHODS IN DATA } \\
\text { COLLECTION }\end{array}$ & Databases & $\begin{array}{l}\text { Inquiries (Questionnaires } \\
\text { and interviews); Direct or } \\
\text { participative Observation; } \\
\text { Content Analysis }\end{array}$ & Observation; Content Analysis \\
\hline NATURE OF RESEARCH & $\begin{array}{l}\text { Quantitative } \\
\text { (Experimental; } \\
\text { Exploratory) }\end{array}$ & $\begin{array}{l}\text { Qualitative } \\
\text { (Explanatory; } \\
\text { Interpretive; Interpretive } \\
\text { Case studies) }\end{array}$ & $\begin{array}{l}\text { Qualitative } \\
\text { (Experimental; Explanatory; } \\
\text { Descriptive; Descriptive Case } \\
\text { studies) }\end{array}$ \\
\hline SAMPLING & Frequent & $\begin{array}{l}\text { Sometimes or not } \\
\text { applicable }\end{array}$ & Never or not applicable \\
\hline $\begin{array}{l}\text { FINDINGS } \\
\text { GENERALIZATION }\end{array}$ & Generalizable & Usually not generalizable & Not generalizable \\
\hline $\begin{array}{l}\text { BUSINESS BOUNDARIES } \\
\text { OF RESEARCH }\end{array}$ & $\begin{array}{l}\text { Financial accounting; } \\
\text { Public Accounting; } \\
\text { Corporate } \\
\text { governance, etc. }\end{array}$ & $\begin{array}{l}\text { Management accounting; } \\
\text { Auditing and internal } \\
\text { controls; Public } \\
\text { Accounting, etc. }\end{array}$ & $\begin{array}{l}\text { Management accounting; } \\
\text { Management control; } \\
\text { Performance analysis; Pricing, } \\
\text { etc. }\end{array}$ \\
\hline
\end{tabular}

Those approaches have their generic substance in the sociological research framework created and developed by Burell and Morgan (1979). Furthermore, the gradual increase in the phenomena complexity requires new and more systematic approaches in their exploration and explanation. Authors as Chua (1986), Laughlin (1995), Ryan et al. (2002), and Sekaran and Bougie (2013), have pursuit that objective by contributing with new insights about the identification and categorization of new research methods and methodology alternatives.

Research is in itself a dynamic field of research because, especially in social sciences, multiple and complex phenomena are currently emerging (markets development, harmonization and standardization requirements, etc.). As argued by Sekaran and Bougie (2013, p. 2): "research [...] is simply the process of findings solutions to a problem after a thorough study and analysis of the situational factors" or, according (Ryan et al., 2002, p. 7), research "is a process of intellectual discovery, which has the potential to transform our knowledge and understanding of the world around us". In businesses fields, research is usually associated to the processes of value creation, performance analysis, knowledge creation and disclo- 
sure, risk mitigation, decision making, and best practices analysis. Hence, business research is understood as the systematic path to achieve a solution or a reasonable understanding for a specific problem.

\section{Scientific and academic knowledge production in accounting}

The boundaries of accounting are quite diffuse once these fields of knowledge intersect multiple scientific domains as corporate finance, taxation, corporate governance, law, strategy, performance analysis, among others. The globalization and complexity of the economic and financial phenomena, over the last decades, have required the search for new approaches and insights towards the identification and comprehensiveness of drivers that can contribute for the explanation of their intrinsic complexity. The consequent harmonization efforts within accounting horizons have put the information quality, its subsequent dissemination, and resources allocation, in the centre of the debate. Thus, the research in those fields should explore, explain and even predict the potential outcomes. Broadly, research in those particular fields tends to be normative, interpretive and descriptive, contributing positively to help individuals and organizations to support their own decisions. As mentioned by Ronen $(2012$, p. 4) "[...] normative research specifies assumptions that descriptive research attempts to verify, and descriptive research documents behaviors that guide normative researchers in formulating their assumptions about the decision-making environment."

Ronen (2012) through a four cell matrix, has summarized the accounting research and its linkage with the objectivity of information usefulness in the decision making process. Approaches were categorized according the attributes (wisdom or foolishness) how researchers see managers and markets. The first matrix axis measures the way how managers use the information available as utility optimizers while the second axis measures the way how researchers see the markets or stakeholders (potential or current users of accounting information). All cells in that theoretical model should converge into a bilateral wisdom perspective. In this case, several accounting issues arise as agency theory applications, financial reporting, signaling, optimal contracting, and performance measures.

Accounting is traditionally divided into two different and complementary fields, according its objectives and scope: financial accounting (external) and management accounting (internal). We can also consider the public accounting as a third line of research, strongly developed in countries like Portugal, Spain and UK. However, this third typology does not differ in substance from the previous ones. Its direct focus is in institutions publicly owned and socially driven such 
as schools, hospitals, ministries, army, and central and local government, among others. It merges both financial and management accounting in its objectives and purposes. As referred by Ryan et al. (2002), financial accounting research has followed, in a broad sense, a positive (or mainstream) approach while management accounting has followed an interpretive or even critical approach. The globalization of markets and accounting harmonization processes and norms, have driven accounting into an international comparison, in terms of convergence issues and in terms of contextual factors (e.g. culture, country, standards implementation, legal systems, economic development, etc.) that affect the utility and use of information by stakeholders. The increase in the use of databases with predictive purposes has driven the research in the external accounting.

Research in pure management accounting theory (Al-htaybat and Alberti-Althtaybat, 2013), and in its related scientific fields, has been marked by its more applied focus (Joahnsson and Siverbo, 2009; Scapens and Bromwich, 2010; Sekaran and Bougie, 2013). It explores the social practices and interprets or criticizes the application of conceptual theories and frameworks in practice (Ryan et al., 2002; Harris and Durden, 2012; Al-Htaybat and Alberti-Alhtaybat, 2013). The case study approach emerges in this context as qualitative (experimental or explanatory) towards the knowledge creation in a timely and spatially limited scope and horizon. In its overview about management accounting practices, Scapens and Bromwich (2010) have identified the main topics under analysis in the last two decades. Topics such as activity based costing, capital budgeting, cost accounting systems and techniques, management accounting practices, and performance measurement, have characterized the major part of scientific projects concluded in this domain. Applied projects (34\%) and institutional theory (19\%) lead the research in the last two decades, respectively. Relating the research methods used, case studies lead the ranking, $24 \%$ in the 90 's and $40 \%$ in the first decade of current century.

Auditing and internal controls intercept both financial, public, and management accounting. These scientific fields have derived from accounting fields and are the result of markets' developments, in particular the increase in the standardization and control needs. Topics as internal controls procedures implementation, risk categorization, and risk detection, have followed the same trend as observed in pure management accounting research. Case study approach (experimental, exploratory or explanatory) is traditionally the most used method in both cases. In contrast, topics such as corporate governance, information quality and risk detection, seems to be closer to the approaches effectively followed by financial accounting, in which a positive or mainstream approach has been implemented. In this particular scope, the research starts with an identified theory, usually emerging from the literature 
review, and expressed in the form of a mathematical model. The theory is used to formulate hypotheses which express relationships between a structured set of variables (Ryan et al., 2002). Its intrinsic inference methodology is based on abstraction, data reduction and sophisticated statistical techniques.

Management control and performance projects are usually associated with topics as management control systems development and implementation, residual income analysis, pricing, capital budgeting, among others. Research in this field is usually practice-oriented (Scapens, 1999) and reported to practioners (Ryan et al., 2002). This evidence is aligned with the increase in management control systems. In globalized economies, performance analysis is the basis for value creation, and strategic and financial positioning achievements. Thus, the experimental and interpretive case study approach emerges as the main research method that best fits the theoretical framework designs and the practice-oriented view required by organizations. The social practices under analysis require a dynamic interaction between researchers and the organizational leaders. It implies that, in many cases, researcher becomes a dynamic participant in the design and implementation of that conceptual framework. Furthermore, this type of research enables the researcher to interpret and criticize the social practices and analyze how outcomes fit with the value creation goals and objectives.

\section{Methodology}

\section{The data source}

The main data source for this research was the Scientific Open Access Repository of Portugal (RCAAP). This repository aims to collect, aggregate and index the scientific content, existing in the open access institutional repositories of the national higher education institutions and other R\&D based organizations. Since its creation, in 2008, that portal was established as a single way of search, discovery, location, and access to thousands of documents. It indexes several scientific and academic documents, namely articles from scientific journals, presentations at seminars and conferences, thesis and dissertations, disseminated from multiple Portuguese higher education repositories. Today, this repository is considered the most updated and reliable database in Portugal for the postgraduate projects that were effectively concluded towards the Ph.D. and MSc degree achievement. We found in the repository, on January 2014, approximately 507000 indexed documents in 69 of categories. It includes approximately 8.400 Ph.D. thesis and approximately $46000 \mathrm{MSc}$ dissertations in all scientific fields. 
That portal is a key embodiment of the Scientific Open Access Repository of Portugal project. This project is an initiative of Agency for the Knowledge Society, developed and managed by the Foundation for National Scientific Computing which has provided a more advanced service on the National Network for Research and Education. It was partially funded by the Knowledge Society Operational Programme.

\section{The variables}

The variables used to identify and categorize the research methods and methodology used by MSc and PhD students in the scientific field of accounting were based on the literature review (Burell and Morgan, 1979; Chua, 1986; Laughlin, 1995; Scapens, 1999; Ryan et al. 2002; Scapens and Bromwich, 2010; Ronen, 2012; Sekaran and Bougie, 2013) and on our own academic observation and experience. All of them were categorized according their own specificities and adjusted to the Portuguese higher education system standards. Those variables are described in Table 2, as follows:

Table 2.

Variables description and framework.

\begin{tabular}{|c|c|c|}
\hline Variable & Acronym & Description \\
\hline FiELD OF RESEARCH & FRES & $\begin{array}{l}\text { Identifies the scientific domains, namely: Financial accounting; } \\
\text { Management accounting; Public accounting; Auditing and internal } \\
\text { controls; Management control and performance; Accounting } \\
\text { History; Research in accounting and auditing; and Other. }\end{array}$ \\
\hline Date of Conclusion & $Y E A R$ & Year of Ph.D. or MSc conclusion. \\
\hline $\begin{array}{l}\text { NATURE OF HIGHER } \\
\text { EDUCATION INSTITUTION }\end{array}$ & TINST & $\begin{array}{l}\text { Typology of Higher Education Institution: Polytechnic school of } \\
\text { management; Faculty of economics; Business school; and Other. }\end{array}$ \\
\hline & TRES1 & Nature of project: Ph.D. project or MSc project \\
\hline CHARACTERISTICS & TRES2 & $\begin{array}{l}\text { Type of project: Thesis (Ph.D.) or Dissertation (MSc); Applied } \\
\text { Project; and Other. }\end{array}$ \\
\hline $\begin{array}{l}\text { APPROACH AND } \\
\text { PERSPECTIVE }\end{array}$ & $A P P R$ & $\begin{array}{l}\text { Mainstream or Positivist; Interpretive; and Critical. (Chua, 1986; } \\
\text { Ryan et al., 2002; Modell, 2010; Scapens and Bromwich, 2010; } \\
\text { Sekaran and Bougie, 2013). }\end{array}$ \\
\hline & $S A M P$ & Use of sampling methods. \\
\hline Main Data Source & $M D S R$ & $\begin{array}{l}\text { Main data source: Database; Inquiry by questionnaire; Inquiry by } \\
\text { interview; Direct or participative observation; Content analysis; and } \\
\text { Other (Sekaran and Bougie, 2013). }\end{array}$ \\
\hline & CSTY1 & Number of case studies: Single; Double; and Multiple. \\
\hline CHARACTERISTICS & CSTY2 & $\begin{array}{l}\text { Nature of case study: Experimental; Exploratory; and Explanatory } \\
\text { (Yin, 1984; Scapens, 1999; Ryan et al., 2002). }\end{array}$ \\
\hline
\end{tabular}


This variables framework intends to characterize, from a qualitative perspective, the academic projects concluded by students towards the achievement of a $\mathrm{Ph} . \mathrm{D}$. or MSc degree. Through an integrated overview, it will be possible to identify and define the state of the art of the national postgraduate scientific production. This approach tried to identify the trends in the accounting research and whether the research is aligned with modern financial and other social phenomena. Through an integrated overlook it is possible to conclude whether the traditional paradigms in the particular fields of accounting have observed any reverse in the last decade.

\section{Association and classification measures}

Association measures have the objective to quantify the strength and direction between two variables towards the diagnosis of potential causal links. In this scope, the most used association measures are the Chi-Square $\left(\chi^{2}\right)$, the Pearson's and Spearman's $(\rho)$ coefficients, and corroboratively the Cramer's V coefficient, the Phi $(\phi)$ coefficient, and even the contingency coefficient. Pearson correlation coefficient measures the strength and direction of the linear association between two quantitative variables while the Spearman coefficient measures the strength and direction of that association, albeit non-parametric, between two variables at least classified as nominal. In our analysis we will run the Spearman coefficient because it is the one that best fits the type of variables used to categorize the Portuguese postgraduate projects. Cramer's V coefficient is also a non-parametric and asymmetric coefficient, used as an association measure between two nominal variables which will be used, in this scope, only as corroborative validation purposes.

Relating classification/categorization measures, we tried the Linear Discriminant Analysis $(L D A)$ as a proxy, in order to identify linear combinations of $n$ variables $\mathrm{X}_{\mathrm{n}}$ that best identify and separate subgroups of appointed individuals, according to the criterion stated in Fisher et al. (1990), in Johnson (1998) or in Johnson and Wicherin (2007). Thus, this criterion is based on the assumption that the possible linear combinations of the observed variables, is intended to find the one in which individuals of each class become more homogeneous, and different $k$ classes become more heterogeneous with each other. This technique has the main objective to identify the internal homogeneity of classes as results by the following formula:

$$
\left\|\left(I_{n}-P_{C}\right) y\right\|^{2}=\sum_{j=1}^{k} \sum_{i=1}^{n_{j}}\left(y_{i}^{(j)}-\bar{y}^{(j)}\right)^{2}
$$

This result is the sum of the variances of $y$ observations in each $k$ classes. The best $y$ derives from the linear combination for which that sum is quite low, since 
this level will reflect the existence of internal classes homogeneity. Furthermore, the heterogeneity among classes which reflects the dispersion of the mean of each class $k$, around the overall average $y$ values, is derived as follows:

$$
\left\|\left(P_{C}-P_{1_{n}}\right) y\right\|^{2}=\sum_{j=1}^{k} n_{j}\left(\bar{y}^{(j)}-\bar{y}\right)^{2}
$$

This statistical methodology has the objective to identify the variables that better can differentiate between multiple groups of individuals, structurally different and mutually exclusive. Its intrinsic assumptions are the normality in the variances distribution and the homogeneity in the variances-covariance's matrix, which can be verified through the Shapiro Wilk and M Box tests, respectively. However, the robustness of this technique allows the tolerance if its basic assumptions are violated (Stevens, 1986), which consolidates, in that case, its application as corroborative evidence.

In this particular research, the LDA technique was run with the main objective to identify which variables really differentiate the postgraduate projects concluded in the scientific fields under analysis, namely in financial accounting, in management accounting, in public accounting, in auditing and internal controls, in management control and performance, among others related scientific fields (variable FRES).

\section{Results and discussion}

In the scientific category of "Accounting, we have validated 760 academic projects [44 (5.8\%) Ph.D. thesis and 716 (94.2\%) MSc dissertations]. All of them were concluded in public and private institutions between 2008 (date of RCAAP creation) and 2013. In the scope of auditing projects, we have excluded from this research all projects related to non-financial auditing approaches (e.g. strategic, management, quality, energetic, taxation, industrial, information systems, among others).

\section{An integrated overview}

After 2010, we have observed an increase in scientific production [2010: 130 projects (17.1\%); 2011: 206 projects $(27.1 \%)$; 2012: 158 projects (20.8\%)], especially in the field of financial accounting and in management control and performance scientific fields. This evidence is certainly related to harmonization of national accounting standards with IASB accounting standards and to the implementation of management control systems as Balanced Scorecard ${ }^{\circledR}$ or other si- 
milar programs. The projects in the scientific field of management control and performance represent approximately $35 \%$ of total. If grouped with the scientific field of financial accounting, those projects represent $60.8 \%$ of the actual concluded projects (Table 3 ).

Table 3.

Fields of research.

\begin{tabular}{lll}
\hline Field of research & $\mathrm{f}_{\mathrm{i}}$ & $\%$ \\
\hline Financial accounting & 194 & 25.5 \\
Management accounting & 66 & 8.7 \\
Public accounting & 36 & 4.7 \\
Auditing and internal controls & 158 & 20.8 \\
Management control and performance & 268 & 35.3 \\
Accounting History & 6 & 0.8 \\
Research in accounting and auditing & 10 & 1.3 \\
Others & 22 & 2.9 \\
\hline Total & 760 & 100 \\
\hline
\end{tabular}

The field of research "Others" includes projects related to learning techniques, ethic codes and complementary governance rules. As evidenced, it has in our research, a residual contribution $(4.3 \%)$.

In the scientific field of financial accounting and auditing, the main topics developed in their academic projects are described as follows:

- Harmonization between international (e.g. IFRS) and national standards;

- IFRS interpretation and compliance;

- Information disclosure and dissemination to stakeholders;

- Accountants perceptions and practices;

- Accounting theory evolution and trends;

- Business combinations and other related parties;

- Transfer pricing practices;

- Internal controls systems identification or implementation;

- Public accounting harmonization;

- Corporate governance practices;

- Auditors' perceptions and practices.

Broadly, the research in this particular field tends to be more normative than in management accounting or management control domains. These projects tend to identify the main strengths and weaknesses in the standards implementation, capturing the perceptions and practices from professionals such as accountants and auditors. 
Relating management accounting and management control, students tend to link the theory and practice through more applied projects in the following topics:

- Inventories measurement (cost of inventories identification, in particular in manufacturing);

- Management control systems implementation and performance analysis (e.g. Balanced Scorecard ${ }^{\circledR}$, Performance Prism, etc);

- Cost accounting practices (e.g. Activity Based Costing; Time Driven Activity Based Costing)

- Inventories management (e.g. Just in Time);

- Information dissemination to internal stakeholders.

These evidences are aligned with literature review, namely the insights derived from Scapens and Bromwich (2010). Financial accounting research has a more normative nature while management accounting has a more applied nature. This confirms the management accounting and management control research is practice-oriented (Scapens, 1999) and reported to practioners in particular public and private organizations (Ryan et al., 2002).

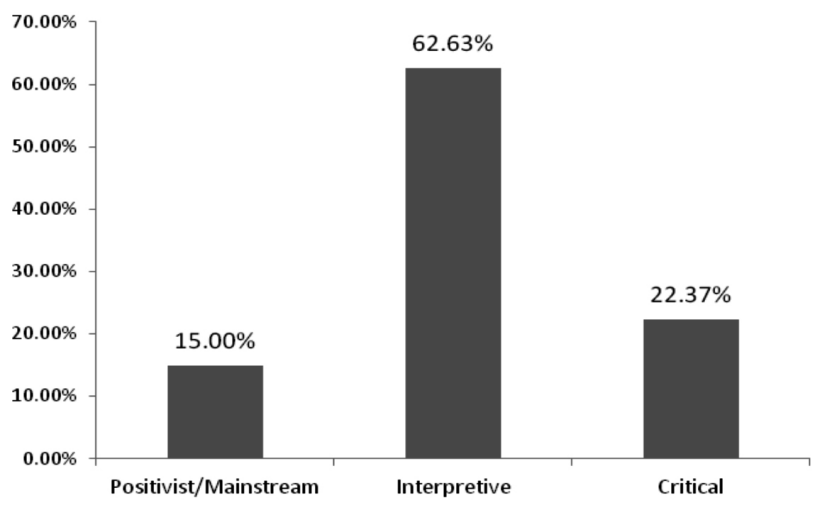

Fig 1. Research approaches and perspectives.

The research approaches and perspectives are fundamentally interpretive (figure 1), in particular in the scientific fields of management accounting, and management control and performance. We have observed an interesting link between academics and organizations in the identification and contribution for best practices achievements. Applied projects have usually the middle management involvement, responsible to certify those practices and capture new insights for the organization. 


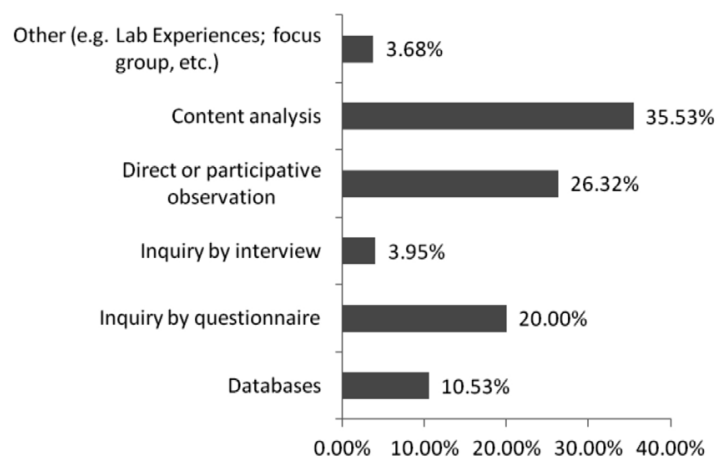

Fig 2. Sources for data collection.

Reports, standards and other documents are the main data sources which supports the content analysis used in $35.5 \%$ of the analyzed projects. This evidence consolidates the interpretive approach described below. Thus, we summarize in the figure 2 the main data sources used by Portuguese students in their academic projects.

Table 4.

Correlation coefficients.

\begin{tabular}{|c|c|c|c|c|c|c|c|c|c|c|}
\hline VAR. & FRES & $Y E A R$ & TINST & TRES1 & TRES2 & $A P P R$ & SAMP & $M D S R$ & CSTY1 & CSTY2 \\
\hline FRES & 1 & & & & & & & & & \\
\hline \multirow{2}{*}{ YEAR } & $0.094^{* *}$ & 1 & & & & & & & & \\
\hline & 0.009 & & & & & & & & & \\
\hline \multirow{2}{*}{ TINST } & $0.178^{* *}$ & $-0.161^{* *}$ & & & & & & & & \\
\hline & 0.000 & 0.000 & & & & & & & & \\
\hline \multirow{2}{*}{ TRES1 } & 0.026 & $0.194^{* *}$ & $-0.165^{* *}$ & & & & & & & \\
\hline & 0.466 & 0.000 & 0.000 & 1 & & & & & & \\
\hline \multirow{2}{*}{ TRES2 } & $0.172^{* * *}$ & 0.048 & $0.071^{*}$ & $0.092^{*}$ & 1 & & & & & \\
\hline & 0.000 & $0.182^{* * * *}$ & 0.050 & 0.011 & & & & & & \\
\hline \multirow{2}{*}{$A P P R$} & $0.143^{* *}$ & 0.059 & -0.022 & $0.069^{* * * *}$ & $0.443^{* *}$ & 1 & & & & \\
\hline & 0.000 & 0.105 & 0.553 & 0.058 & 0.000 & & & & & \\
\hline \multirow{2}{*}{$S A M P$} & $-0.229^{* *}$ & $-0.081^{*}$ & -0.008 & $-0.150^{* * *}$ & $-0.373^{* *}$ & $-0.565^{* *}$ & & & & \\
\hline & 0.000 & 0.026 & 0.828 & 0.000 & 0.000 & 0.000 & & & & \\
\hline \multirow{2}{*}{ MDSR } & 0.007 & $0.125^{* *}$ & $-0.099^{* * *}$ & $0.203^{* *}$ & $0.132^{* *}$ & $0.388^{* * *}$ & $-0.578^{* *}$ & & & \\
\hline & 0.839 & 0.001 & 0.006 & 0.000 & 0.000 & 0.000 & 0.000 & & & \\
\hline \multirow{2}{*}{ CSTY1 } & $-0.266^{* *}$ & -0.012 & $-0.121^{*}$ & $-0.102^{*}$ & $-0.089^{* * * *}$ & $-0.127^{*}$ & -0.029 & $0.088^{* * * *}$ & & \\
\hline & 0.000 & 0.812 & 0.018 & 0.047 & 0.084 & 0.013 & 0.572 & 0.087 & & \\
\hline \multirow{2}{*}{ CCSTY2 } & $-0.391^{* *}$ & $-0.115^{*}$ & $-0.272^{* *}$ & $0.258^{* *}$ & $0.209^{* *}$ & -0.022 & -0.004 & $0.117^{*}$ & $0.111^{*}$ & \\
\hline & 0.000 & 0.025 & 0.000 & 0.002 & 0.000 & 0.673 & 0.935 & 0.023 & 0.031 & \\
\hline
\end{tabular}

$* \mathrm{p}<0.05 * * \mathrm{p}<0.01 * * * \mathrm{p}<0.1$ 
Relating variables association, several significant correlations can be observed. As expected, a significant correlation was observed between main data source (MDSR) and type of project variables (TRES1 and TRES2), approach and perspective $(A P P R)$ and other related concepts such as the sampling theory use $(S A M P)$. The variable $F R E S$ and $A P P R$ has also a significant correlation at a $1 \%$ significance level $(\rho=0.143 ; p=0.000)$ which confirms the traditional evidence that financial accounting tends to implement positive approaches (databases and inquires use) while management accounting and management control tend to focus on interpretive or even critical approaches (Ryan et al., 2002; Joahnsson and Siverbo, 2009; Scapens and Bromwich, 2010; Sekaran and Bougie, 2013). This means that, higher education institutions and organizations are closer in the management accounting field than in the financial accounting field. This evidence confirms the generalist scope of financial accounting and the specific scope of management accounting.

\section{The association overview}

Through an integrated crossed analysis, and complimentarily to the Spearman's correlation (Table 4), it was also possible to identify some important associations between variables (Table 5) which represent, in this scope, an important corroborative evidence. Surprisingly, top business schools, most of them listed in the international rankings, tend to develop thesis/dissertations (80.3\%) instead of applied projects $(19.7 \%)$. These schools tend to implement positivist approaches towards the identification of relations, statistically significant, between variables that best explain the phenomenon under analysis. This evidence is probably aligned with the opportunity to present and publish their researches in international conferences and journals, and subsequent recognition achievement by the academic and scientific communities. The dissemination of academic research is one of the main requirements towards the recognition and integration in those international rankings, including international certification (e.g. AACSB certification).

Broadly, primary data sources and approaches effectively followed a positivist (or mainstream), interpretive, and critical approach which corroborates the literature (Burell and Morgan, 1979; Yin, 1984; Ryan et al., 2002; Sekaran and Bougie, 2013) about research methods and methodology $\left(\chi^{2}=572.888 ; \mathrm{df}=10 ; \mathrm{p}=0.000\right)$. Positivist approach usually use databases as the main source while interpretive approach usually use inquiries by questionnaire (30\%), direct or participative observation $(23.5 \%)$, or content analysis $(39.9 \%)$, as the main data source. Critical approach uses the observation $(50.6 \%)$ or content analysis $(34.1 \%)$ in primary data collection. Case studies have, in $47.4 \%$, an explanatory nature and an explor- 
atory aim, in $44.2 \%$. These approaches are used especially on applied projects $\left(\chi^{2}=105.184 ; \mathrm{df}=4 ; \mathrm{p}=0.000\right)$ which broadly confirms the evidence stated in literature, namely in Scapens (1999) and in Scapens and Bromwich (2010).

Table 5 .

Most significant association measures.

\begin{tabular}{cccccc}
\hline Variable $\mathrm{X}_{\mathrm{n}}$ & Variable $\mathrm{X}_{\mathrm{p}}$ & $\mathrm{c}^{2}$ & $\mathrm{df}$ & $\begin{array}{c}\text { Asymp. Sig. } \\
(2 \text {-sided })\end{array}$ & Cramer's V \\
\hline \multirow{6}{*}{ FRES } & TINST & 155.729 & 21 & 0.000 & 0.261 \\
& TRES1 & 31.797 & 7 & 0.000 & 0.205 \\
& TRES2 & 63.077 & 14 & 0.000 & 0.204 \\
& APPR & 101.899 & 14 & 0.000 & 0.259 \\
& SAMP & 111.498 & 7 & 0.000 & 0.383 \\
& MDSR & 237.707 & 35 & 0.000 & 0.250 \\
\multirow{5}{*}{ PPPR } & CSTY1 & 48.279 & 10 & 0.000 & 0.252 \\
& CSTY2 & 110.124 & 15 & 0.000 & 0.311 \\
& TINST & 47.164 & 6 & 0.000 & 0.176 \\
\multirow{3}{*}{ MDSR } & TRES2 & 160.057 & 4 & 0.000 & 0.325 \\
& MDSR & 572.888 & 10 & 0.000 & 0.614 \\
& TRES1 & 55.417 & 5 & 0.000 & 0.270 \\
& TRES2 & 199.952 & 10 & 0.000 & 0.363 \\
& TINST & 65.177 & 15 & 0.000 & 0.169 \\
& SAMP & 415.646 & 5 & 0.000 & 0.740 \\
\hline
\end{tabular}

As observed in the Table above, FRES is associated with most of the other variables considered for analysis in the current framework. As illustrative of this finding, the scientific field of research is associated with variables as TINST $\left(\chi^{2}=155.729 ; \mathrm{df}=21 ; \mathrm{p}=0.000\right), \operatorname{MDSR}\left(\left(\chi^{2}=237.707 ; \mathrm{df}=35 ; \mathrm{p}=0.000\right)\right.$, APPR $\left(\chi^{2}=101.899 ; \mathrm{df}=14 ; \mathrm{p}=0.000\right)$, and $\operatorname{SAMP}\left(\chi^{2}=111.498 ; \mathrm{df}=7 ; \mathrm{p}=0.000\right)$, among others. However, we should also underline that $62.6 \%$ of the projects follow an interpretive approach while $22.4 \%$ follow a critical approach. Interpretive and critical approaches are used fundamentally in management control and performance projects $(97.8 \%)$ while positivist approach is broadly used in financial accounting projects $(29.9 \%)$, in particular in the accounting standards harmonization processes and in practioners perceptions and practices identification. This evidence corroborates the assumptions stated in Joahnsson and Siverbo, (2009), in Scapens and Bromwich (2010) and in Sekaran and Bougie (2013). Thus, financial accounting is closer to practioners while management accounting is closer to organizations and other external agencies.

In order to understand which variables best distinguish the fields of research explored by Portuguese students in their Ph.D or MSc programs, we have also per- 
formed a Linear Discriminant Analysis (LDA), taking into consideration its basic assumptions. Despite the failure to comply with the assumption of homogeneity of variance-covariance matrix, we corroborate the assertion of Stevens (1986) by considering that it is a very robust technique with regard to the violation of those assumptions. Given its corroborative nature, consider this evidence as a proxy, keeps it with a high degree of utility in this particular context. Based on this approach, the variables that best fit with "Field of research" are the variables CSTY1, CSTY2, and INST. Function 1 explains $59.2 \%$ of the overall variance (Wilks' Lambda $=0.582$ and $\chi^{2}=198.263 ; \mathrm{df}=36 ; \mathrm{p}=0.000$ ), function 2 (variable $M D S R$ ) explains $33.2 \%$ of the global variance (Wilks' Lambda $=0.791$ and $\chi^{2}=85.723 ; \mathrm{df}=24 ; \mathrm{p}=0.000$ ) while function 3 (variables APPR, TRES1, TRES2 and SAMP) explains $16.8 \%$ of that variance (Wilks' Lambda $=0.902$ and $\chi^{2}=37.660 ; \mathrm{df}=14 ; \mathrm{p}=0.001$ ). This represents a cumulative variance explanation of $99.1 \%$. Thus, case study methodology is used fundamentally in the scientific fields of "Management Control and Performance" (54.7\%), "Auditing and Internal Controls" (15.8\%) and "Financial Accounting" (14.2\%). This confirms most of the evidences achieved by Scapens (1999) and Scapens and Bromwich (2010).

\section{Conclusions}

Knowledge creation is based on unsolved paradigms which assumptions drive researchers towards multiple methodologies and methods that permit to explore and interpret the world. Traditionally, in the scope of accounting and related scientific domains, the financial accounting research has traditionally followed a positive approach while management accounting (including management control and performance) is more permissive to qualitative approaches such as case studies or even interpretive theoretical models. Although not generalizable, applied projects allow and facilitate the understanding in depth of a certain phenomena in an organizational environment. Mainstream (positivism), interpretive and critical perspectives are the main approaches that have driven the academic research carried out by Portuguese PhD and MSc students in the scientific field of accounting.

The projects concluded in the last six years, and disseminated in the national repository, have implemented, in $85 \%$ of cases, an interpretive or critical approach, in particular in the scientific field of management accounting and management controls and performance. This evidence confirms that higher education institutions are closer to practioners (accountants, auditors) in the financial accounting issues while are closer to organizations for management accounting and management control issues. Content analysis (35.5\%), direct or participative 
observation $(26.3 \%)$, and inquiry by questionnaire $(20 \%)$ were the main sources used in data collection. Variables as type of institution, number of case studies and data source are the ones that best differentiate the research made in the fields considered for the current research. Complementarily, business schools listed in international rankings tend to implement positivist approaches while other institutions implement all research methods without any significant differentiation. These evidences achieved corroborate the trend referred and explored in the literature. Financial accounting tends to implement positivist approaches while management accounting, and management controls and performance tend to implement interpretive or even critical approaches. This evidence is more consistent when we are faced with the implementation of strategic and management control systems such as the implementation of Balanced Scorecard ${ }^{\circledR}$ programs or other related systems and tools.

Broadly, we cannot conclude for a reserve in traditional paradigms of accounting research. However, the accounting harmonization efforts tend to explore the practioners perceptions and organizations' strengths and weaknesses in the harmonization internal processes. It would be useful an increase of organization's contribution for the standards set up and subsequent best practices identification.

To extend the number of academic projects and the business fields can be the forthcoming research steps towards a more integrated overview. The methods and methodology implemented in other complimentary scientific fields (e.g. Taxation; Strategic management; Supply chains and logistics) can contribute for the evidence consolidation in the broad scope of business.

\section{References}

Al-Htaybat; Khaldoon and Alberti-Alhtaybat, L. von (2013). Management Accounting Theory Revisited: Seeking to Increase Research Relevance. International Journal of Business and Management, 8 (18), 12-24.

Burrell, G. and Morgan, G. (1979). Sociological Paradigms and Organizational Analysis. London: Heinemann Educational Books.

Chua, W. F. (1986). Radical developments in accounting though. Accounting Review, 61 (4), 601 632.

Choo, C. W. (1996). The Knowing Organizations: How Organizations Use Information to construct Meaning, Create Knowledge and Make Decisions, International Journal of Knowledge Management, 16 (5), 329-338.

Dandago, K. I and Shaari, N. A. B. (2013). Effects of Focus of Accounting Research on the Quality of Accounting Education in Malysian Universities, Asian Economic and Finance Review, 3 (10), 1371-1385. 
Fisher, R. A., Yates, F. and Bennett, J. H. (1990). Statistical Methods, Experimental Design, and Scientific Inference. Oxford Science Publications, Oxford.

Harris, Jason and Durden, C. (2012). Management Accounting Research, An Analysis of Recent Themes and Directions for the Future, Journal of applied Management Accounting Research, 10 (2), 21-42.

Johansson, Tobias and Siverbo, S. (2009). Why is research on management accounting change not explicitly evolutionary? Taking the next step in the conceptualization of management accounting change. Management Accounting Research, 20, 146-162.

Johnson, D. E. (1998). Applied Multivariate Methods for Data Analysis, Brooks/Coole Publishing Company, Pacific Grove.

Johnson, R. A. and Wicherin, D. W. (2007). Applied Multivariate Statistical Analysis. (6 ${ }^{\text {th }}$ ed.). Prentice Hall, New Jersey.

Laughlin, R. (1995). Empirical research in accounting: alternative approaches and a case for middle-range thinking. Accounting, Auditing and Accountability Journal, 8 (1), 63-87.

Modell, Sven (2010). Bridging the paradigm divide in management accounting research: the role of mixed methods approaches. Management Accounting Research, 21, 124-129.

Quinn, J. B., Anderson, P. and Finkelstein, S. (1996). Managing Professional Intellect: Making the Most and the Best. Harvard Business Review, March-April, 71-80.

Ronen, Joshua (2012). The state of accounting research: objectives and implementation. Asia-Pacific Journal of Accounting \& Economics, 19 (1), 3-11.

Ryan, Bob, Scapens, R. and Theobald, M. (2002). Research method \& Methodology in Finance \& Accounting. ( $2^{\text {nd }}$ ed.). London: Thomson.

Scapens, R. W. (1999). Broadening scope of management accounting: from a microeconomic to a broader business perspective. Maandblad voor Accountancy en Bedrijfseconomie, 73 (12), 638-649.

Scapens, R. W. and Bromwich, M. (2010). Management Accounting Research: 20 years on. Management Accounting Research, 21, 278-284.

Stevens, J. (1986). Applied Multivariate Statistics for the Social Sciences. New Jersey: Lawrence Erlbaum Associates.

Sekaran, U. and Bougie, R. (2013). Research Methods for Business. (6 ${ }^{\text {th }}$ ed.). West Sussex: John Wiley \& Sons.

Senik, R. (2009). Understanding Accounting Research Paradigms: Towards Alternative Methodologies. Integration and Dissemination, 5-8.

Sullivan, P. H. (2000). Value-Driven Intellectual Capital: How to Convert Intangible Corporate Assets into Market Value. New York: John Wiley \& Sons.

Teece, David J. (1998). Capturing Value form Knowledge Assets: The New Economy, Markets for Know-How, and Intangible Assets. California Management Review, 40 (3), 55-79.

Tiwana, A. (2000). The Knowledge Management Toolkit: Orchestring IT, Strategy, and Knowledge Platforms. ( $2^{\text {nd }}$ ed.). New Jersey: Prentice Hall.

Von Krogh, G. (1998). Care in Knowledge Creation, California Management Review, 40 (3), 133 153.

Yin, R. K. (1984). Case Study Research, Design and Methods. Sage, Beverly Hills. 